\title{
Screening Assay Establishment for Toxigenic Bacteria from PSP-producing Dinoflagellate Alexandrium tamarense Cultures
}

\author{
Xiaoling Zhang ${ }^{\text {a }}$ \\ Key Laboratory of East China Sea \& Oceanic Fishery Resources Exploitation and Utilization of \\ Ministry of Agriculture (MOA), East China Sea Fisheries Research Institute, Chinese Academy of \\ Fishery Sciences, Shanghai, 200090, China \\ ${ }^{a}$ zhxl@ecfs.ac.cn
}

Keywords: PSP toxins, Alexandrium tamarense, Toxigenic bacteria, Screening Assay

Abstract. Paralytic shellfish poisoning (PSP) toxins are potent neurotoxins mainly produced by marine dinoflagellates. However, the increasing number of findings of toxin-producing bacteria in dinoflagellate intracellular cells supports the hypothesis of the bacterial origin of PSP toxins. Although toxigenic bacteria could be isolated from toxic dinoflagellates, it was not clearly proven whether the isolated bacterial strains based on culture-dependent manner and the corresponding intracellular bacteria were the same because of microbial unculturability and shorting of the genetic evidence. This paper aims to demonstrate the development of a screening assay for toxigenic bacteria from marine dinoflagellate $A$. tamarense based on molecular analysis of the possible sxtA gene for the toxic PSP biosynthesis.

\section{Introduction}

Paralytic shellfish poisoning (PSP) toxins are potent neurotoxins comprising of saxitoxin (STX) which are blocking the voltage-gated sodium channels on excitable cells, and thus leading to severe neurological symptoms and even death [1]. Up to now, totally 58 STX analogs has been found [2]. The main producers of PSP are marine dinoflagellates, in particular, Alexandrium spp., Pyrodinum bahamense var. compressum and Gymnodinium catenatum [3], but some freshwater cyanobacteria such as Aphanizomenon flos-aquae, Anabaena circinalis and Lyngbya wollei [4]. Interestingly, PSP toxins have been also detected in intracellular bacteria isolated from toxin-producing dinoflagellates [5]. Silva first suggested the theory of a bacterial origin of PST in 1979, with the first reported PST-producing intracellular bacterium marine Moraxella sp. (PTB-1) isolated from the dinoflagellate nucleus of Alexandrium tamarense [6]. The subsequent increasing number of finding of toxin-producing bacteria in the cells of dinoflagellate supports Silva's hypothesis [7]. There is also increasing evidence that there are specific symbiosis bacterial taxa associated with phytoplankton, indicating the presence of specific selective mechanisms, and implying that the symbiosis bacteria have some function to the benefit of the alga, and these interactions could be the product of co-evolution between bacteria and algae over millions of years [8]. Studies on the role of toxin-producing symbiosis bacteria in the marine ecosystem are considered to be becoming more important. The evolutionary history that resulted in the curious cross-kingdom distribution of STX-synthesis remained unclear. Increasing number of studies have reported the direct observation of intracellular bacteria in toxic species of dinoflagellate [9-12].

Although toxigenic bacteria could be isolated from toxic dinoflagellates, it was not clearly proven whether the isolated bacterial strains and the corresponding intracellular bacteria were the same because of microbial unculturability and shorting of the genetic evidence. The purpose of this paper is 
to demonstrate the development of a screening assay for toxic bacteria from marine dinoflagellate Alexandrium tamarense based on molecular analysis of the possible sxtA gene, the initial starting gene during the toxic PSP biosynthesis pathway.

\section{Materials and Methods}

\section{Sample Culture}

The toxic dinoflagellate Alexandrium tamarense (880\#) was collected and kindly provided by Prof. Hung-Non Chou at National Taiwan University. An axenic culture of Alexandrium tamarense was cultured in $\mathrm{f} / 2$ medium. Cultures were kept at $28^{\circ} \mathrm{C}$ and a $12 \mathrm{~h}$ light: $12 \mathrm{~h}$ dark cycle. With the light intensity of ca. 200 umol photons $\mathrm{m}-2 \cdot \mathrm{S}-1$.

\section{Bacterial Isolation}

Cultivable bacteria were isolated and maintained on a marine Zobell 2216 prepared with aged filtered natural seawater, supplemented with GSe trace elements and vitamins were used as necessary [13]. acterial isolation was performed by harvesting $1 \mathrm{ml}$ of a late-logarithmic phase $A$. tamarense culture by brief centrifugation (4000 $\mathrm{g}$ for $20 \mathrm{~min}$ ). The spent medium was removed and the algal cell pellet resuspended in $100 \mu \mathrm{L}$ of sterile seawater and vortexed. The cell suspension was diluted 10 -fold and $100 \mu \mathrm{L}$ of each dilution spread onto 2216 agar plates and incubated in the dark at $25^{\circ} \mathrm{C}$ for $6-10$ days. Bacterial colonies with distinct colony morphology were picked . Bacterial isolates were grown in 2216 broth, glycerol was added $(25 \% \mathrm{v} / \mathrm{v})$, and the cells were stored at $-80^{\circ} \mathrm{C}$.

\section{PSP Analysis by LC-MS}

LC-MS analysis of the STX toxin production of the isolated microbial strain was performed according to the method reoprted previously LC-MS analysis of the STX toxin production of the isolated microbial strain was performed according to the method reoprted previously $[8,14]$.

\section{Assay Development}

Genomic DNA of the samples was extracted using Wizard® DNA Kit (Promega, Madison, USA) following the manufacturer's instruction. The quality of extracted DNA was checked by $0.8 \%$ agarose gel electrophoresis and spectrophotometry (optical density at $260 \mathrm{~nm} / 280 \mathrm{~nm}$ ratio). The sxtA1 region of bacterial DNA were amplified by PCR [13]. The sxtA gene A1 region of bacteria was amplified using the designed primers as shown in Table 1. PCR amplifications of the sxtA gene A1 region were performed. The amplicon mixture was subject to sequencing (Illumina, San Diego, CA, USA). Alignment of the obtainded sequences were performed by blast using GenBank database.

\section{Results and Discussion}

Total 3 positive DNA samples of intracellular bacteria strains isolated from A. tamarense culture were tested as for selectivity of the primers for PCR amplification. Table 1 shows the total 10 primers based on the conserved region of the gene of $s x t \mathrm{~A} 1$ region. Based on the agarose gel electrophoresis analysis for PCR amplification products (Fig. 1), the of sxt 3-F and 4-R was selected as the primer for PCR amplification. 
Table 1 The tested primers for PCR in this study

\begin{tabular}{ll}
\hline Primers & Sequences $\left(5^{\prime} \rightarrow 3^{\prime}\right)$ \\
$0-\mathrm{F}$ & CCGTAGGTGAACCTGCG \\
$1-\mathrm{R}$ & CCTCCGCTTATTGATAT \\
$2-\mathrm{F}$ & ATGCTAACATGGGAGTCA \\
$3-\mathrm{R}$ & GGGTCCAGTAGATGTTGAC \\
$4-\mathrm{F}$ & TAGTAGGAGTAGCKACG \\
$5-\mathrm{R}$ & TCCTTCCTRGACCACGA \\
$6-\mathrm{F}$ & GCAAGTATCTCCGCAGGCT \\
$7-\mathrm{R}$ & GTGGAGGAGCATGTTGACAG \\
$8-\mathrm{F}$ & TGCAGCGMTGCTACTCCTACT \\
$9-\mathrm{R}$ & GGTCGTGGTCYAGGAAGGAG \\
\hline
\end{tabular}

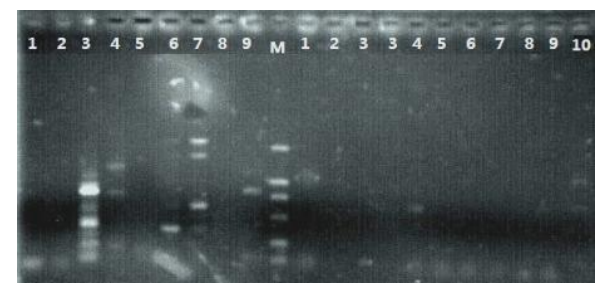

Fig. 1 Primers selection based on PCR amplification of sxtA1 region of positive bacteria DNA

It has been reported that, SxtA, the unique starting gene for STX synthesis in cyanobacteria, possiblely origins from an actinobacterial specie or a Proteobacterium by independent horizontal gene transfers (HGTs) and gene fusion [5-7]. In order to elucidate the relationship of the intracellular bacteria with

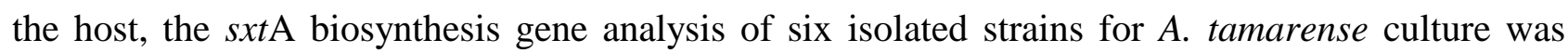
performed. The result is shown Fig 2. It indicated that, five isolated intracellular bacteria strains from toxic A. tamarense have the sxtA1 gene for the biosynthetic intermediate of PSP toxins, STX. Addtionly, this bacteria stain has possible toxic biosynthetic gene as its gene sequence obtained in this study has high similarity with dinoflagellate $s x t$ A gene. This finding implyes that the development of the rapid method such as in situ DNA hybridication using specific DNA-targeted probes for the the study of the interaction relationship between the intracellular bacteria and the host toxic dinoflagellate.

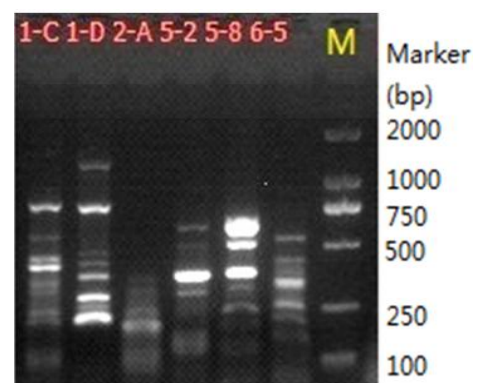

Fig. 2 PCR amplification of sxtA1 region of the intracellular bacteria DNA isolated from $a$. tamarense cultures 


\section{Acknowledgment}

This work was supported by the funds from National Non-profit Institutes (East China Sea Fisheries Research Institute) (No. 2012T08) and the National Natural Science Foundation of China (NSFC) (No. 41206093).

\section{References}

[1] Zhang F, Xu X, Li T, Liu Z. Shellfish toxins targeting voltage-gated sodium channels. Mar Drugs. 2013; 11(12):4698-4723.

[2] Thottumkara AP, Parsons WH, Du Bois J. Saxitoxin. Angewandte Chemie International Edition, 2014; 53(23): 5760-5784.

[3] Etheridge SM. Paralytic shellfish poisoning: seafood safety and human health perspectives. Toxicon, 2010; 56(2): 108-122.

[4] Dantzer WR, Levin RE. Bacterial influence on the production of paralytic shellfish toxins by dinoflagellated algae. Journal of Applied Microbiology, 1997; 83(4): 464-469.

[5] Kodama M, Ogata T, Sakamoto S, Sato S, Honda T, Miwatani T. Production of paralytic shellfish toxins by a bacterium Moraxella sp. isolated from Protogonyaulax tamarensis. Toxicon, 1990; 28(6): 707-714.

[6] Gallacher S, Smith EA. Bacteria and paralytic shellfish toxins. Protist, 1999; 150(3): 245-255.

[7] Gallacher S, Flynn KJ, Franco JM, Brueggemann EE, Hines HB. Evidence for production of paralytic shellfish toxins by bacteria associated with Alexandrium spp.(Dinophyta) in culture. Applied and Environmental Microbiology, 1997; 63(1): 239-245.

[8] Green DH, Llewellyn LE, Negri AP, Blackburn SI, Bolch CJ. Phylogenetic and functional diversity of the cultivable bacterial community associated with the paralytic shellfish poisoning dinoflagellate Gymnodinium catenatum. FEMS Microbiology Ecology, 2004; 47(3): 345-357.

[9] Jasti S, Sieracki ME, Poulton NJ, Giewat MW, Rooney-Varga JN. Phylogenetic diversity and specificity of bacteria closely associated with Alexandrium spp. and other phytoplankton. Appl. Environ. Microbiol. 2005; 71(7): 3483-3494.

[10]Kodama M, Sakamoto S, Koike K. Symbiosis of bacteria in Alexandrium tamarense. Harmful and toxic algal bloom. Intergovernmental Oceanographic Commission of UNESCO, Paris, 1996; 351-354.

[11] Moustafa A, Loram JE, Hackett JD, Anderson DM, Plumley FG and Bhattacharya D. Origin of saxitoxin biosynthetic genes in cyanobacteria. PloS one, 2009; 4(6): e5758.

[12] Orr RJ, Stüken A, Murray SA, Jakobsen KS. Evolution and distribution of saxitoxin biosynthesis in dinoflagellates. Marine Drugs, 2013; 11(8): 2814-2828.

[13]Zhang XL, Tian XQ, Ma LY, Feng B, Liu QH, Yuan LD, Yang Q. Biodiversity of the Symbiotic Bacteria Associated with Toxic Marine Dinoflagellate Alexandrium tamarense. Journal of Biosciences and Medicines, 2015, 3(06): 23-28.

[14]Zhang XL, Feng B, Cai YQ, Yu HJ. Development and application of tandem LC-MS method for the determination of paralytic shellfish poisoning toxins for pollution monitoring. Applied Mechanics and Materials, 2011, 55:51-56. 